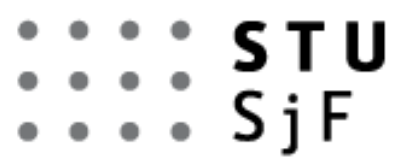

DE GRUYTER OPEN

\title{
A PILOT STUDY IN ORDER TO EXAMINE THE RELATIONSHIP BETWEEN THE DEGREE OF VISUAL IMPAIRMENT OF PATIENT AND HIS POSTURAL STABILITY
}

\author{
JURECZKO Mariola ${ }^{1}$, JURECZKO Pawel ${ }^{1}$, KRZYSZTOFIK Mateusz ${ }^{2}$ \\ ${ }^{1}$ Silesian University of Technology, Faculty of Mechanical Engineering, Institute of Theoretical and Applied \\ Mechanics, Konarskiego 18 A, 44-100 Gliwice, Poland, e-mail: Mariola.Jureczko@polsl.pl, \\ Pawel.Jureczko@polsl.pl \\ ${ }^{2}$ Students Scientific Society Biomechatronics Faculty of Mechanical Engineering, Silesian University of \\ Technology, Konarskiego 18 A, 44-100 Gliwice, Poland
}

\begin{abstract}
The main aim of the pilot study was to evaluate the relationship between degree of visual impairment of patient and his postural stability. The article contains basic explanation and requirements for stabilography research. The paper also describes statistic analysis of influence of visual impairment on postural stability opposed to control group (people perfectly sighted). These results allowed us to verify the approved research plan.
\end{abstract}

KEYWORDS: stabilography, platform stabilometry, platform Zebris, various degree of visual impairment

\section{Introduction}

Proper and stable human's posture is necessary to realize most of free actions and moves. This is the cause why most of clinic tests which tests physical activity includes postural stability research. The main goal of these researches is recognition of patient's postural instability, description of its source, and recognition of possibility to classify patient to group of people with fall risk. Complexity of balance control problem is shown however when it comes to handicap caused by senility or illness.

Eyesight is very important organ in balance regulation process. Using eyesight body's spatial orientation is determined basing on objects placed close to human. Its loss or deterioration causes huge changes in life of affected with this problem person. Totally congenitally blind persons or those who lost their eyesight in the early stage of life walks easier independently than those who lost their eyesight later because of e.g. diabetic retinopathy [1] $\div$ [5]. That why reasons and time of eyesight loss has significant impact on gait and postural stability. Because of lack of eyesight or it's malfunction people are forced to rely on another senses such as balance or sense of space.

According to commonly used criteria blind people are defined as persons with totally twoeye blindness or persons with practical two-eye blindness whose visual acuity after correction in better eye isn't better than 5\% of normal visual acuity, and person whose field of vision isn't better than $20^{\circ}$ (tunnel vision). People low vision are those whose visual acuity after optical correction is up to $25 \%$ of full visual acuity [2]. From medical point of view people are classified as totally blind, partially blind (people residually seeing) and visually impaired.

Complexity of problems for blind people related to gait and postural stability is noticeably big. Presented studies were designed to find and describe dependencies between degree 
of visually handicapped and body-balance problems. Unfortunately, postural research of human body cannot be done using methods relevant to mechanical devices such as proposes an analytical scheme for stability analysis in turning process in [6] and [7].

\section{$2 \quad$ Material and methods}

Researches were conducted on groups of patients with the following of degrees of visual impairment (there were no other dysfunctions legally or biological):

- $\quad$ group 1: moderate degrees of visually handicapped;

- $\quad$ group 2: totally congenitally blind;

- $\quad$ group 3: partially blind (patients residually seeing).

The results of acquired measurements were compared with average results of control group. In every group studies were conducted for 5 patients. All examined patients were interested to participate in the study. Anthropometric and posturography of all patients test were made only once. Patient's body mass and height were measured using an electronic weight and height scale in accordance with generally accepted principles. The accuracy of body mass measurement was $0.1 \mathrm{~kg}$ and body height $0.1 \mathrm{~cm}$. Mean values, standard deviation (SD) and range of values of basic anthropometric variables are presented in Table 1.

Table 1 Mean values, standard deviation (SD) and range of values of basic anthropometric variables of patients

\begin{tabular}{|c|c|c|c|}
\hline \multirow{4}{*}{ group 1 } & anthropometric variables & mean \pm SD & range \\
\cline { 2 - 4 } & age [years] & $62 \pm 2.5$ & $58-65$ \\
\cline { 2 - 4 } & body mass [kg] & $74.3 \pm 2.5$ & $72-77$ \\
\hline \multirow{4}{*}{ group 2 } & body height [cm] & $170.3 \pm 6.7$ & $161-180$ \\
\cline { 2 - 4 } & age [years] & $62.3 \pm 2.8$ & $58-66$ \\
\cline { 2 - 4 } & body mass [kg] & $71.7 \pm 2.5$ & $69-74$ \\
\hline \multirow{3}{*}{ group 3 } & body height [cm] & $174 \pm 3.7$ & $170-180$ \\
\cline { 2 - 4 } & age [years] & $26 \pm 1.1$ & $25-28$ \\
\cline { 2 - 4 } & body mass [kg] & $69.4 \pm 3.8$ & $65-74$ \\
\hline Control & body height [cm] & $172.2 \pm 3.9$ & $166-179$ \\
\cline { 2 - 4 } group & age [years] & $25.4 \pm 0.4$ & $25-26$ \\
\cline { 2 - 4 } & body mass [kg] & $68.6 \pm 5.2$ & $61-74$ \\
\cline { 2 - 4 } & body height [cm] & $169.8 \pm 5.96$ & $160-179$ \\
\hline
\end{tabular}

It is known that accuracy of stability measurements is dependent on conditions during tests. Because of that presented results of research in this article are made according to recommendations included in [8].

Postural stability was tested using two diagnostic machines:

- Zebris treadmill FDM-TDM, including software that allows gait and load analysis in static and dynamic conditions. 
- Stabilographic platform AMT1, including software that allows measurements of ground reaction forces, foot point of contact with the ground, centre of pressure $(\mathrm{CoP})$ in real time.

Tested patient takes free position with hands lowered along the body and foots without shoes putted on hip width. In this position were done some tests, then patients were obligated to take three positions in variants with open (variant is marked as $\mathbf{O E}$ ) and closed eyes - this one wasn't applied to 2'nd group (this variant is marked as $\mathbf{C E}$ ):

- standing still on both legs (position marked as S)

- $\quad$ standing on left leg (position marked as $\mathbf{L L}$ )

- standing on right leg (position marked as RL).

Comparison of stabilograms' parameters received from test with eyes open and closed, allows to assess the role of the visual senses involved in postural control. By measuring pressure force on ground and moment of force location of centre of pressure has been found $(\mathrm{CoP})$, which in static environment is projection of centre of gravity $(\mathrm{CoG})$ on support plane. Six different motion parameters of the CoP have been evaluated:

- $S P$ - total path length, on both axes, in [mm].

- $\quad S P A P$ - statokinesiogram path length on the OY axis (the sagittal plane), in [mm].

- $S P M L$ - statokinesiogram path length on the OX axis (the coronal plane), in [mm].

- $M A$ - the mean amplitude (radius) of the CoP, on both axes, in [mm].

- $M V-$ mean velocity of the CoP movement, on both axes, in [mm/s].

- $S A$ - sway area of the CoP point, in $\left[\mathrm{mm}^{2}\right]$.

\section{$3 \quad$ Analysis of variance - theory}

Analyzed the CoP parameters are linked to each other. It's been verified that distribution of these parameters is normal, and variations are all equal. During research 4 independent group were compared, because of that one - way ANOVA method was chosen to verify hypothesis of mean values equality of many experiments.

Idea of analysis of variance is comparison of dispersion (of variance) of dependent variables in tested groups divided because of values of independent variables. During analysis differences between groups was measured using one - way ANOVA analysis method.

An $\alpha$ - level F-test of null hypothesis rejects if [10] $\div[14]$ :

$$
F=\frac{\mathrm{MST}_{\mathrm{r}}}{\mathrm{MSE}}>f_{a-1, v, \alpha},
$$

where:

$\mathrm{MST}_{\mathrm{r}} \quad$ - variation between groups means,

MSE - variation within groups means,

$f_{a-1, v, \alpha} \quad$ - the upper $\alpha$ critical point of the central F-distribution with $a-1$ and v degree of freedom,

$a-1 \quad-$ the degrees of freedom for treatment mean square,

$v=N-a-$ the degrees of freedom for residual mean square, 
$\alpha \quad-$ significance level. Assumption $\alpha=0.05$,

a - the number of independent parameters,

$\mathrm{N}$

- total number of observations.

Rejection of null hypothesis in analysis of variance doesn't mean that analysis ends. Here it can be only assumed that there are important static differences between compared groups in mean value of tested variable. Anyway there is nothing known about main differences that are between groups. In case when differences are between more than 2 mean values simple t-test can't be used. It is based on standard error between mean values and where errors increases it can lead to $1^{\text {st }}$ kind error. Mentioned error can be avoided using dedicated test post hoc which takes into account multiply of comparisons [10] $\div[14]$.

Tukey - Kramer test (often referred to as the HSD test - Honestly Significant Difference test) is used extensively to make pairwise comparisons among means. The value HSD is given by the formula [12] and [14]:

$$
H S D=q_{\alpha, k, N-k} \cdot \sqrt{\frac{M S E}{n}},
$$

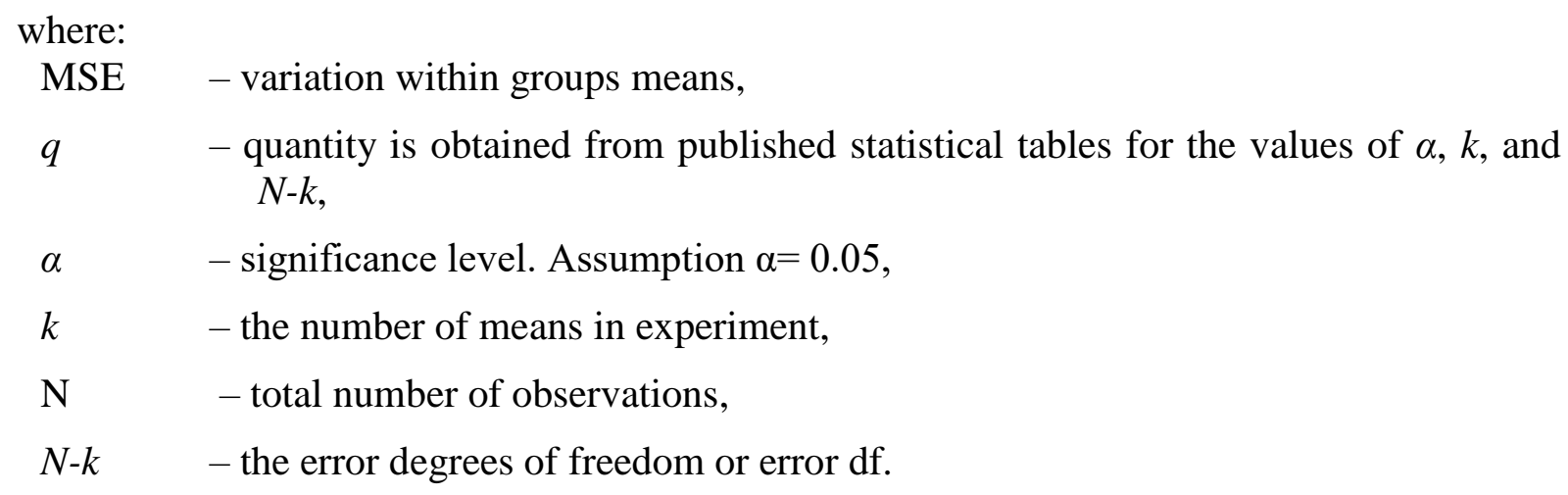

After appointment of HSD value, next thing to do is comparison of mean values of each researched group with each other. If the absolute difference is greater than HSD, then the two group means are considered statistically different at the appropriate level of $\alpha$. If the absolute difference is not greater than HSD, then two group means are not statistically different. It's important to remember that procedure is only done if the overall p-value for the ANOVA is less than or equal to 0.05 (according to [11] and [14]).

\section{$4 \quad$ Statistical analysis of experiments results}

The main goal of a pilot study was validation of the test procedure i.e. selection of patients for individual research group, applied measure instruments, body positions during tests. Results from statistical analysis obtained from pilot studies are only demonstrative.

Experiments results for all groups of patient, three positions in variants with open and close eyes were developed statistically. Results were subjected to one - way ANOVA variance analysis. In situation where developed results allowed to reject null hypothesis, according to equation (1), the Tukey-Kramer test was executed. After developing HSD values, according to equation (2) next step was comparison of mean values of researched group with each other. This allows to verify, if both groups are statistically significant.

Apart from that, for each research configuration dependence between motion parameter of the CoP and group are presented graphically. This is presented by box plots underneath. 
Tables 2 and 3 contains box plots describing comparison of motion parameters of the CoP of the $\mathbf{L} \mathbf{L}$ test with closed and open eyes for each researched group, respectively.

Next tables 4 and 5 contains results of one - way ANOVA and Tukey-Kramer tests for CE and $\mathbf{O E}$ variants for the $\mathbf{L L}$ test.

Table 2 Comparison of all motion parameters of the test LL with closed eyes

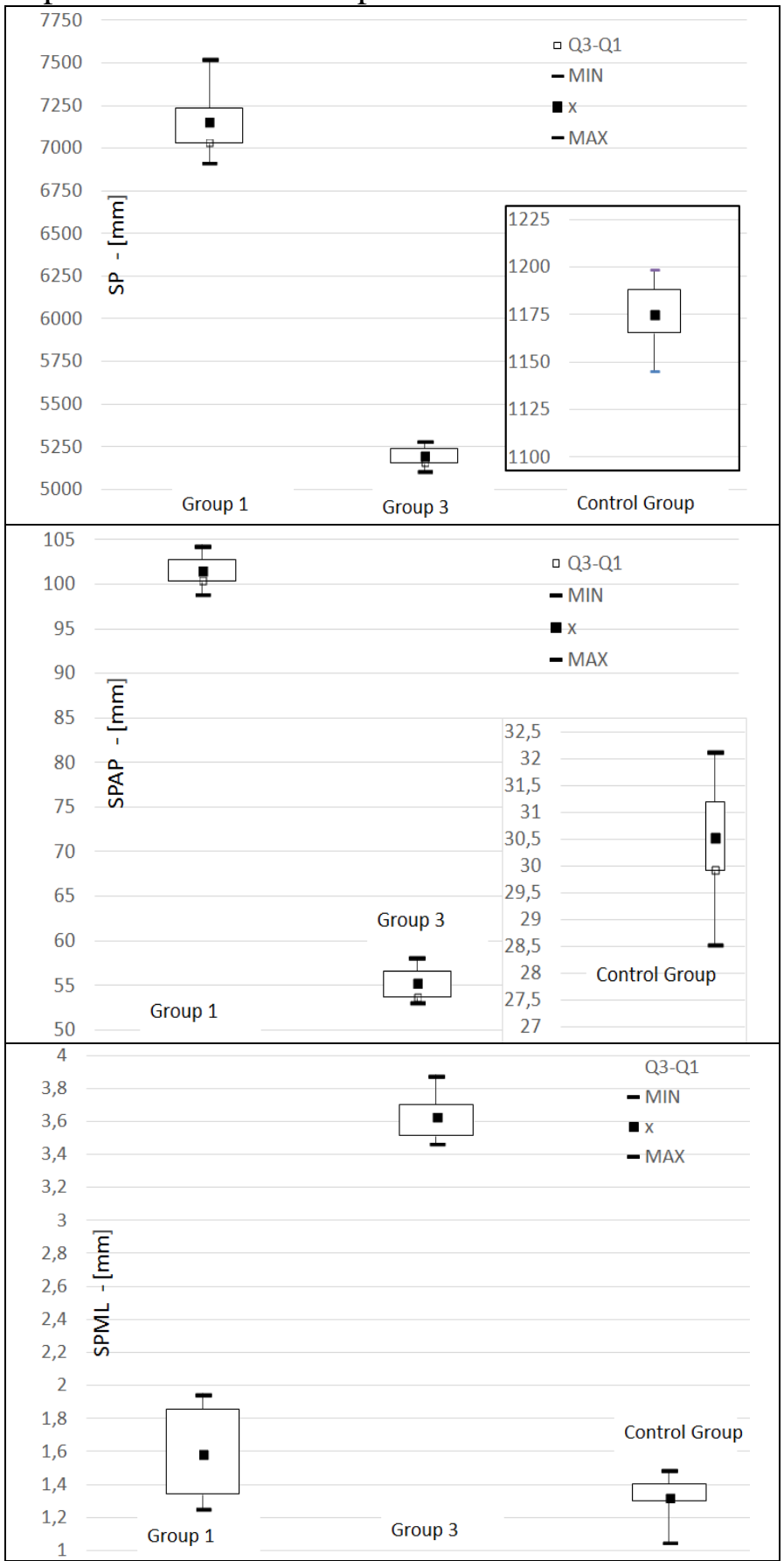




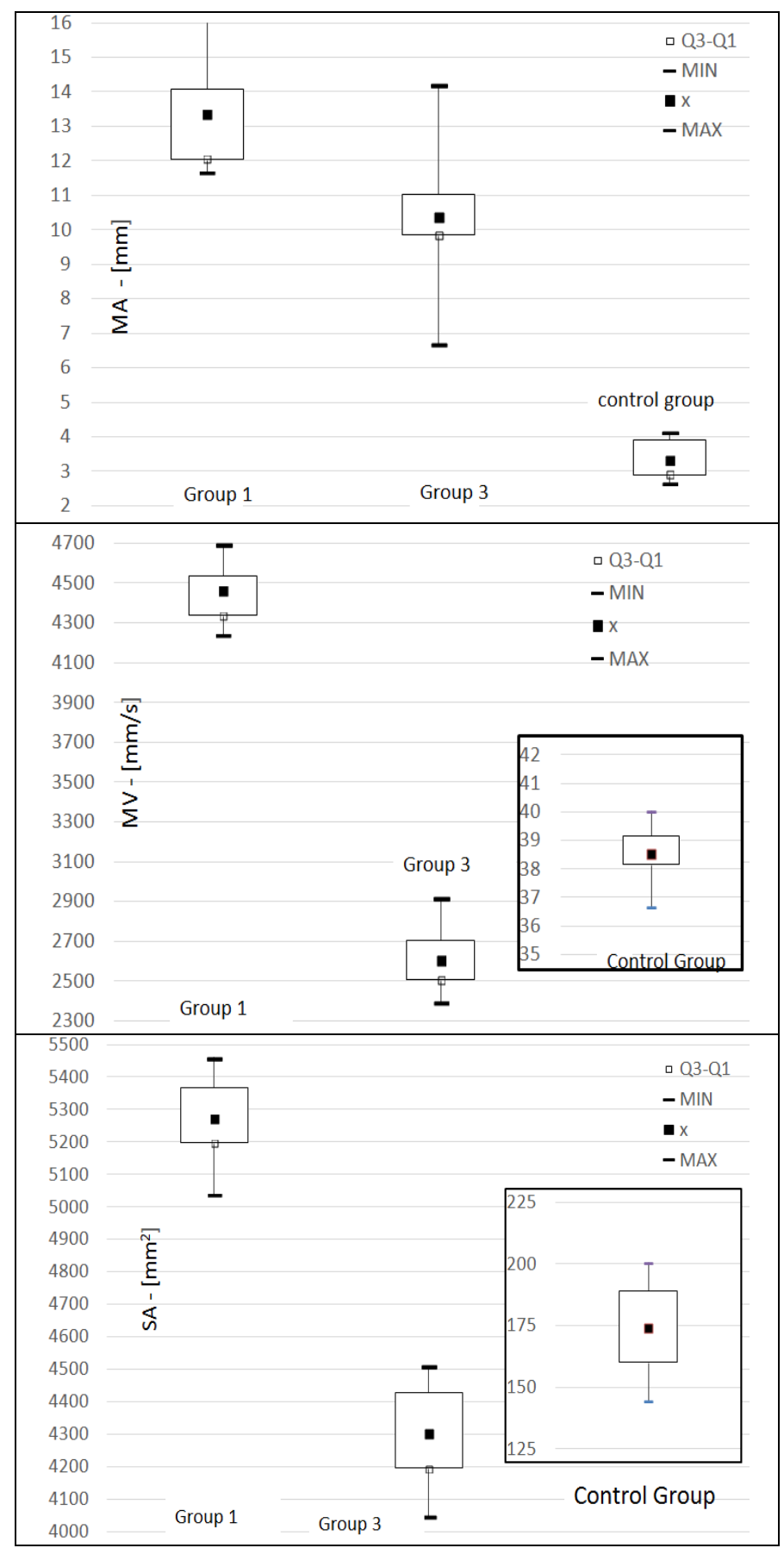


Table 3 Comparison of all motion parameters of the test LL with opened eyes

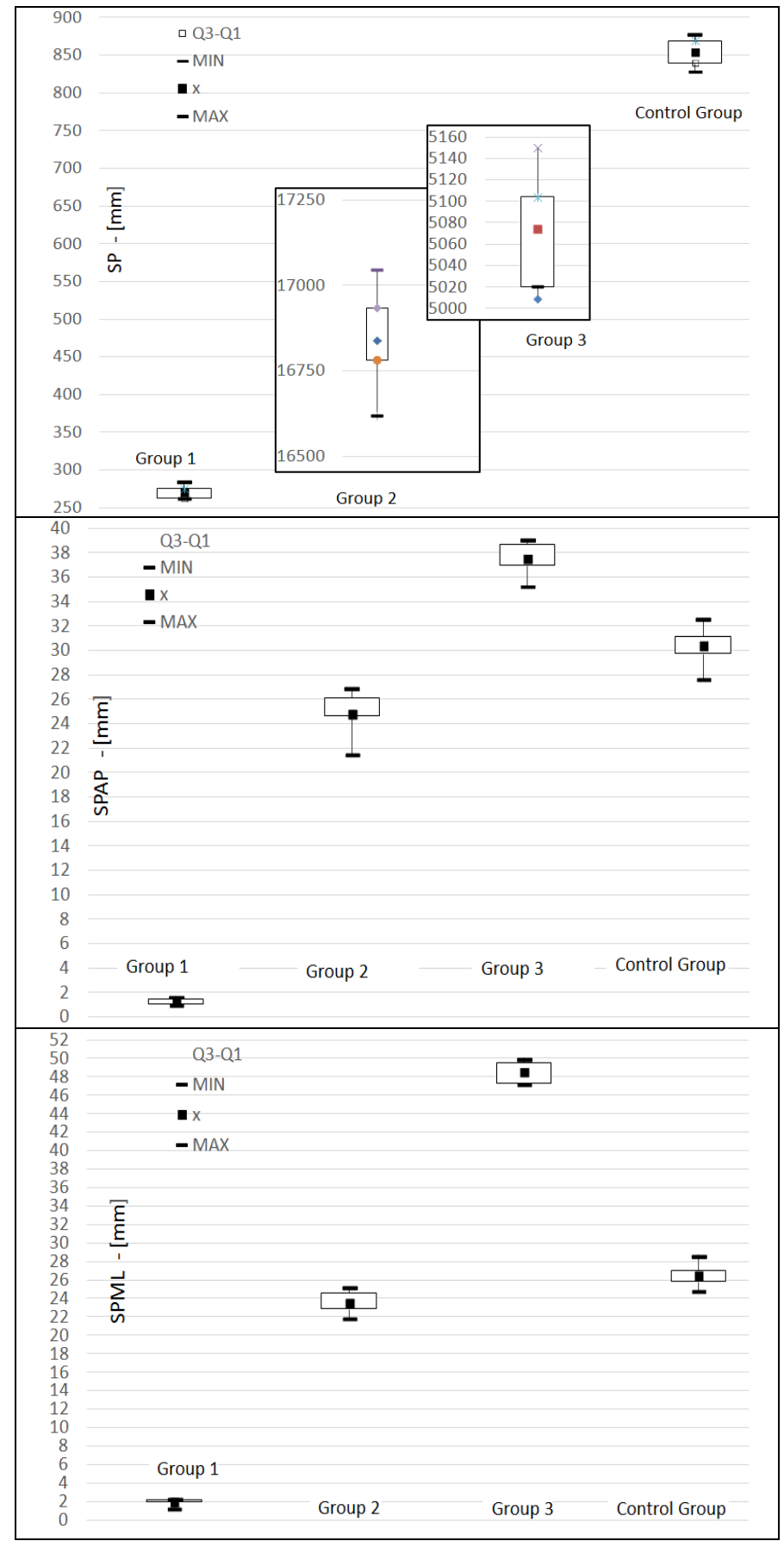




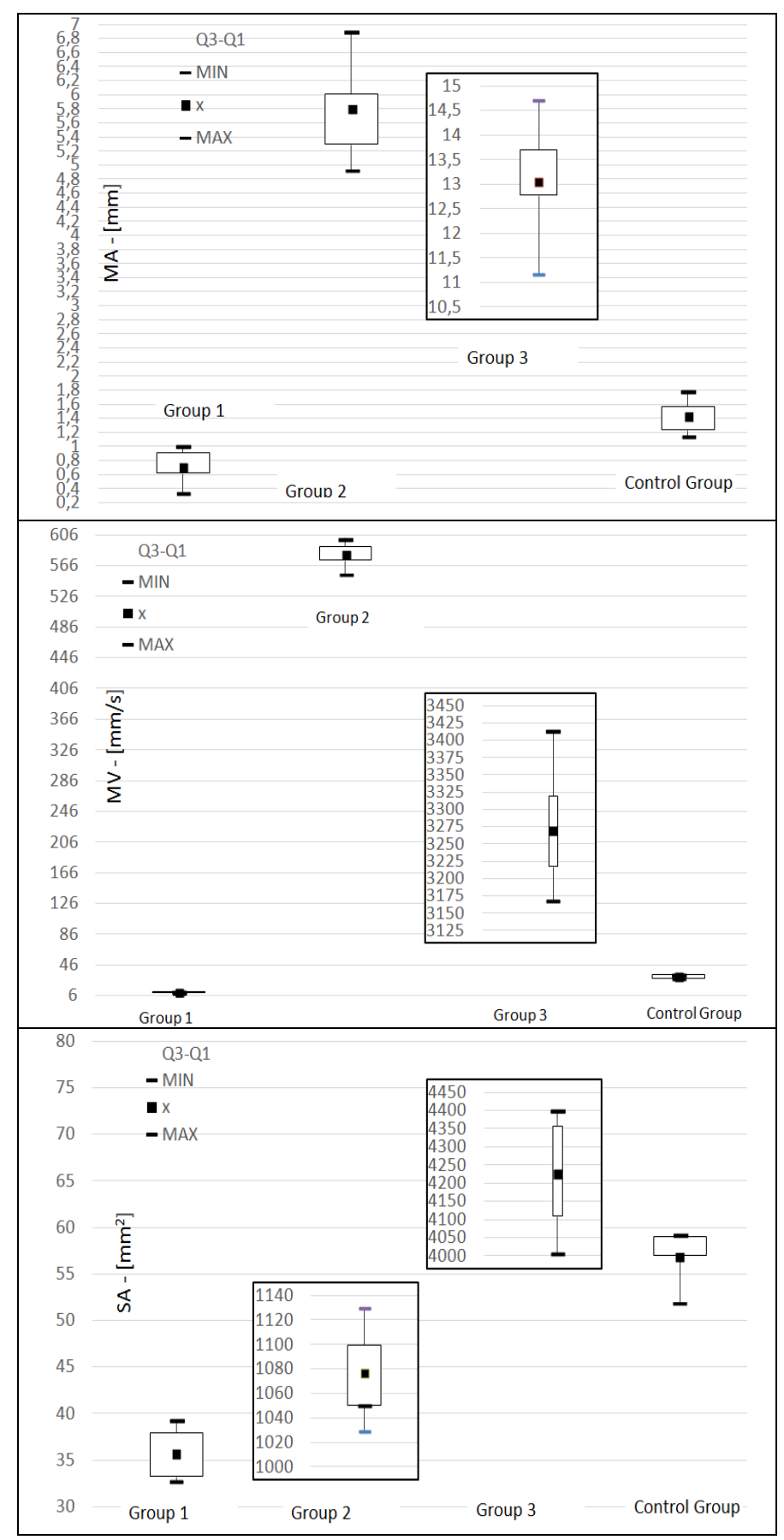

Table 4 Results of ANOVA and HSD tests of motion parameters of CoP for LLCE

\begin{tabular}{|l|c|c|c|c|c|c|}
\hline & \multicolumn{2}{|c|}{ Anova } & Tukey's test & Group 1 and & Group 1 and \\
group 3 & control group & $\begin{array}{c}\text { Group 3 and } \\
\text { control group }\end{array}$ \\
\hline FP & F-test & $f_{a-1, r, \alpha}$ & HSD & $\mathbf{1 9 5 8 , 3 7}$ & $\mathbf{5 9 8 0 , 4 2 4}$ & $\mathbf{4 0 2 2 , 0 5 4}$ \\
\hline SPAP & 1789,18 & 3,8853 & 3,21107 & $\mathbf{4 6 , 1 8 6}$ & $\mathbf{7 0 , 9 9}$ & $\mathbf{2 4 , 8 0 4}$ \\
\hline SPML & 158,0839 & 3,8853 & 0,37853 & $\mathbf{2 , 0 4 4}$ & 0,2616 & $\mathbf{2 , 3 0 5 6}$ \\
\hline$M A$ & 36,4666 & 3,8853 & 3,2151 & 2,958 & $\mathbf{1 0 , 0 2 3 2}$ & $\mathbf{7 , 0 6 5 2}$ \\
\hline$M V$ & 981,7266 & 3,8853 & 267,1418 & $\mathbf{1 8 5 6 , 0 5 2 6}$ & $\mathbf{4 4 2 1 , 5 0 8 6}$ & $\mathbf{2 5 6 5 , 4 5 6}$ \\
\hline$S A$ & 1196,043 & 4,2565 & 309,1059 & $\mathbf{9 3 0 , 5 3 7 8}$ & $\mathbf{5 0 9 6 , 8 3 0 7}$ & $\mathbf{4 1 2 6 , 2 9 3}$ \\
\hline
\end{tabular}


Table 5 Results of ANOVA and HSD tests of motion parameters of CoP for LLOE

\begin{tabular}{|c|c|c|c|c|c|c|c|c|c|}
\hline & \multicolumn{2}{|c|}{ Anova } & & \multirow{2}{*}{$\begin{array}{c}\text { Group } 1 \text { and } \\
\text { group } 2\end{array}$} & \multirow{2}{*}{$\begin{array}{c}\text { Group } 1 \text { and } \\
\text { group } 3\end{array}$} & \multirow{2}{*}{$\begin{array}{c}\text { Group 1 and } \\
\text { control } \\
\text { group }\end{array}$} & \multirow{2}{*}{$\begin{array}{c}\text { Group } 2 \text { and } \\
\text { group } 3\end{array}$} & \multirow{2}{*}{$\begin{array}{c}\text { Group } 2 \text { and } \\
\text { control } \\
\text { group }\end{array}$} & \multirow{2}{*}{$\begin{array}{c}\text { Group } 3 \text { and } \\
\text { control } \\
\text { group }\end{array}$} \\
\hline & & 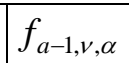 & & & & & & & \\
\hline & 365,4 & & & 16567,8 & & & & & \\
\hline$D A$ & & & & & & & & & 262 \\
\hline$P M L$ & 99,44 & & & 21,566 & 46,598 & & & 936 & 20384 \\
\hline$A$ & 5,305 & 3,2388 & 年 & 5,09832 & & & & & \\
\hline W & & 3,2388 & 9,7359 & 570,4031 & 3258 & 20,3368 & 268 & 550, & 3238,34 \\
\hline & 6,25 & 3,2388 & ,336 & $\mid 1041,142$ & 4190,445 & 21,1565 & 3149,299 & 1019,99 & 4169,29 \\
\hline
\end{tabular}

Tables 6 and 7 contains box plots describing comparison of motion parameters of the CoP of the RL test with closed and open eyes for each researched group, respectively.

Next tables 8 and 9 contains results of one - way ANOVA and Tukey-Kramer tests for CE and $\mathbf{O E}$ variants for the $\mathbf{R L}$ test.

Table 6 Comparison of all motion parameters of the test $\mathbf{R L}$ with closed eyes

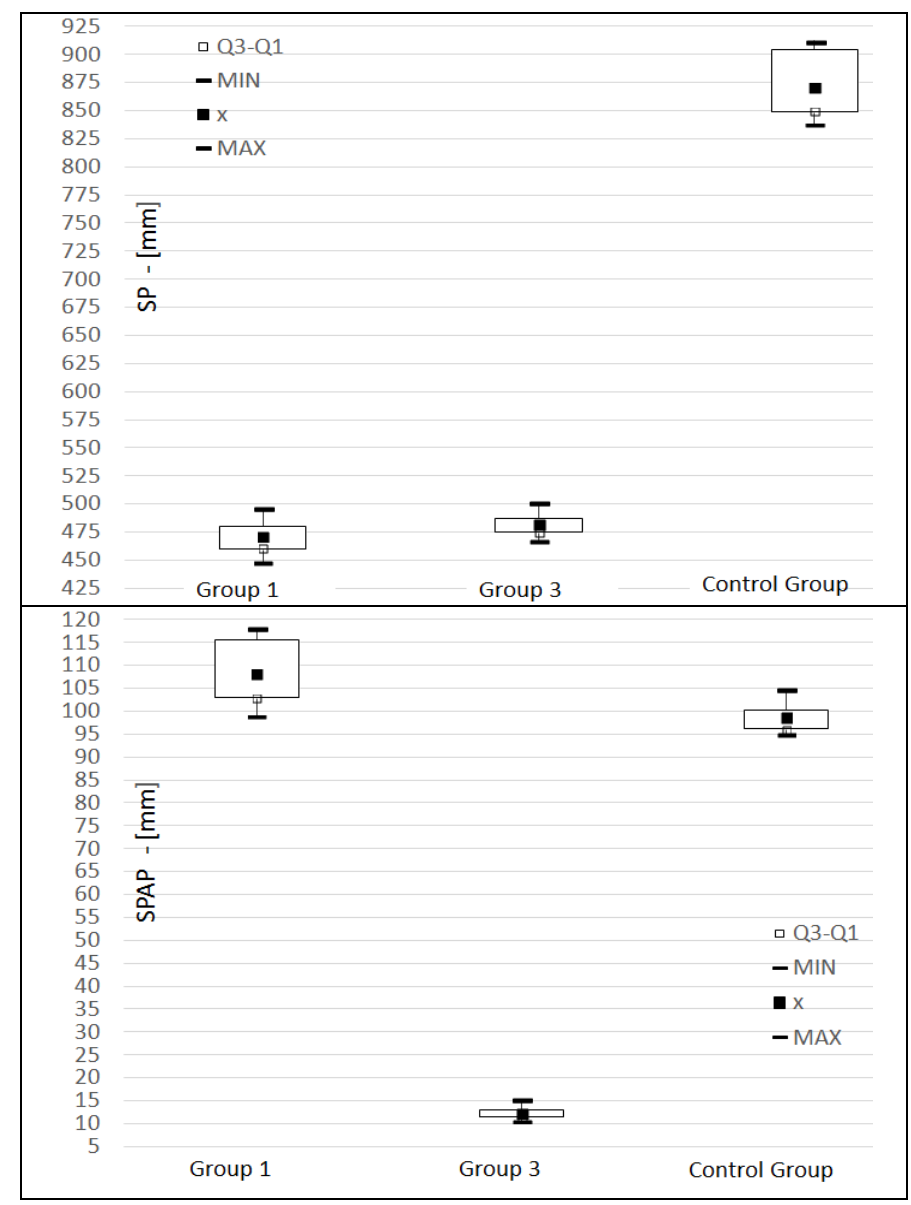




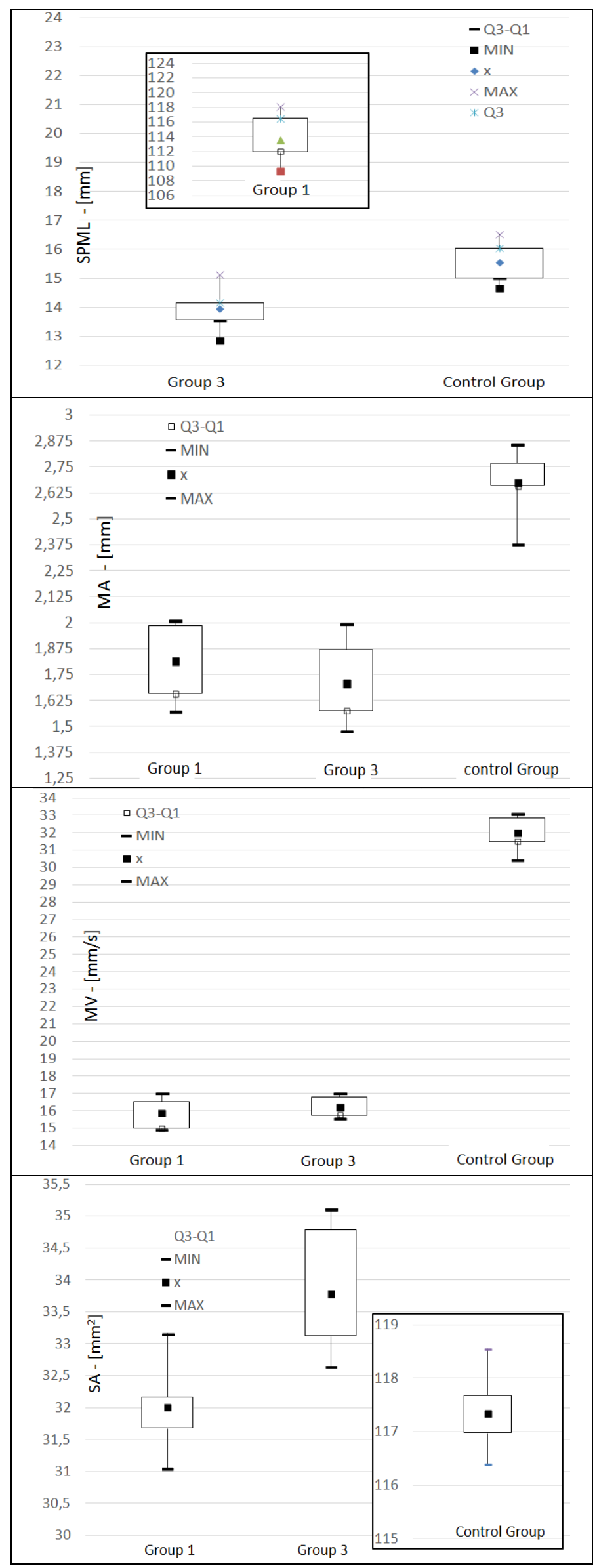


Table 7 Comparison of all motion parameters of the test RL with open eyes

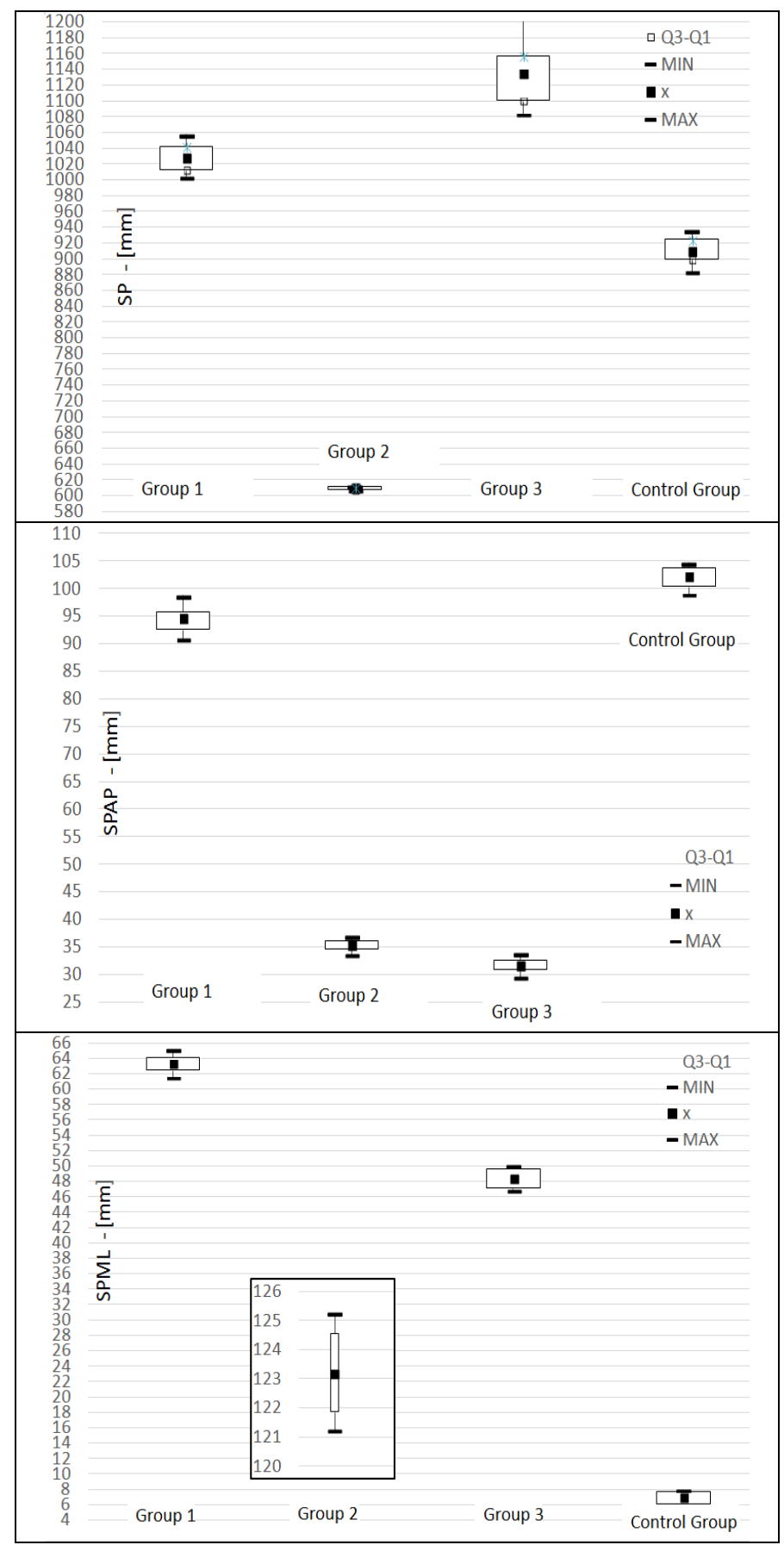




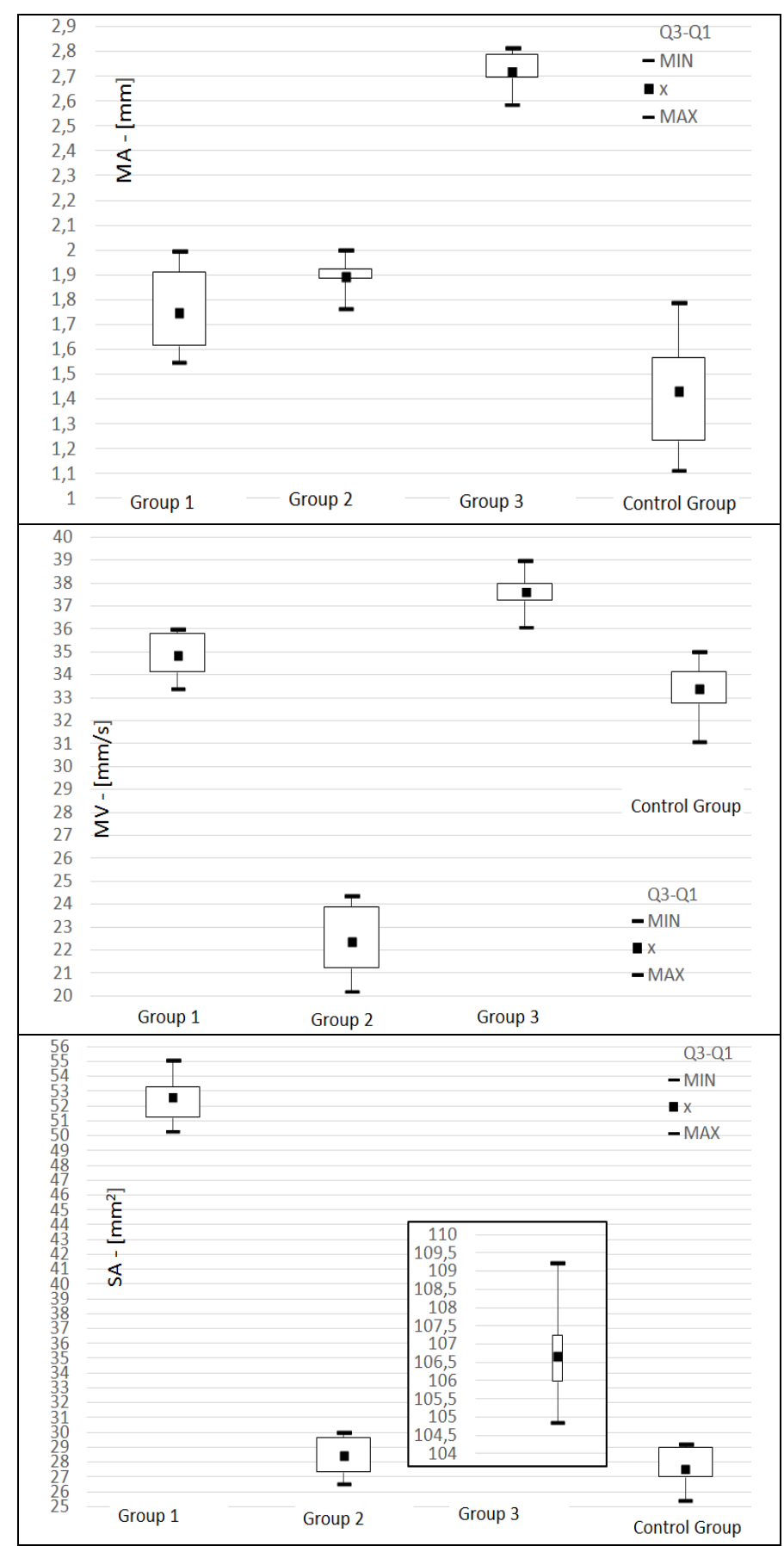

Table 8 Results of ANOVA and HSD tests of motion parameters of CoP for RLCE

\begin{tabular}{|c|c|c|c|c|c|c|}
\hline & \multicolumn{2}{|c|}{ Anova } & Tukey's test & Group 1 and & Group 1 and & Group 3 and \\
\hline & F-test & $f_{a-1, v, \alpha}$ & HSD & group 3 & control group & control group \\
\hline$S P$ & 451,2 & 3,8853 & 40,389 & 10,859 & 399,48 & 388,623 \\
\hline SPAP & 479,26 & 3,8853 & 9,088 & 95,802 & 9,534 & 86,268 \\
\hline SPML & 3419,4 & 3,8853 & 3,6803 & 99,664 & 98,066 & 1,598 \\
\hline$M A$ & 35,717 & 3,8853 & 0,3347 & 0,1071 & 0,86 & 0,96713 \\
\hline$M V$ & 509,86 & 3,8853 & 1,537 & 0,32 & 16,098 & 15,778 \\
\hline$S A$ & 14461,3 & 3,8853 & 1,5288 & 1,771 & 85,334 & 83,563 \\
\hline
\end{tabular}


Table 9 Results of ANOVA and HSD tests of motion parameters of CoP for RLOE

\begin{tabular}{|c|c|c|c|c|c|c|c|c|c|}
\hline & \multicolumn{2}{|c|}{ Anova } & \multirow{2}{*}{$\begin{array}{c}\begin{array}{c}\text { Tukey's } \\
\text { test }\end{array} \\
\text { HSD }\end{array}$} & \multirow{2}{*}{$\begin{array}{c}\text { Group } 1 \text { and } \\
\text { group } 2\end{array}$} & \multirow{2}{*}{$\begin{array}{c}\text { Group } 1 \text { and } \\
\text { group } 3\end{array}$} & \multirow{2}{*}{$\begin{array}{c}\text { Group } 1 \text { and } \\
\text { control } \\
\text { group }\end{array}$} & \multirow{2}{*}{$\begin{array}{c}\text { Group } 2 \text { and } \\
\text { group } 3\end{array}$} & \multirow{2}{*}{$\begin{array}{c}\text { Group } 2 \text { and } \\
\text { control } \\
\text { group }\end{array}$} & \multirow{2}{*}{$\begin{array}{c}\text { Group } 3 \text { and } \\
\text { control } \\
\text { group }\end{array}$} \\
\hline & test & $j$ & & & & & & & \\
\hline & 7719 & & & & & & 524,6 & & \\
\hline$D A$ & & & & & & & & & \\
\hline$P M L$ & 26,62 & 3 & $2,+7,0 J$ & ,865 & & 56,3742 & $\mathbf{7 4 , 7 3 8}$ & & 41502 \\
\hline$A$ & 7,9753 & 3,2388 & 0,3201 & & & & & & ועדנ, ו \\
\hline & 115,871 & 3,2388 & 2,51758 & 12,4775 & 2,7646 & 1,4616 & 15,2421 & 11,01586 & 4,22624 \\
\hline & & 3,2388 & & 24,1311 & $\mathbf{5 4 , 0 7 8 7}$ & 25,0423 & 78,2098 & & 79,1209 \\
\hline
\end{tabular}

Table 10 and table 11 contains box plots describing comparison of motion parameters of the $\mathrm{CoP}$ of the $\mathbf{S}$ test with closed and open eyes for each researched group, respectively.

Next tables 12 and 13 contains results of one - way ANOVA and Tukey-Kramer tests for $\mathrm{CE}$ and $\mathrm{OE}$ variants for the $\mathbf{S}$ test.

Table 10 Box plot of all motion parameters of the test $\mathbf{S}$ with closed eyes

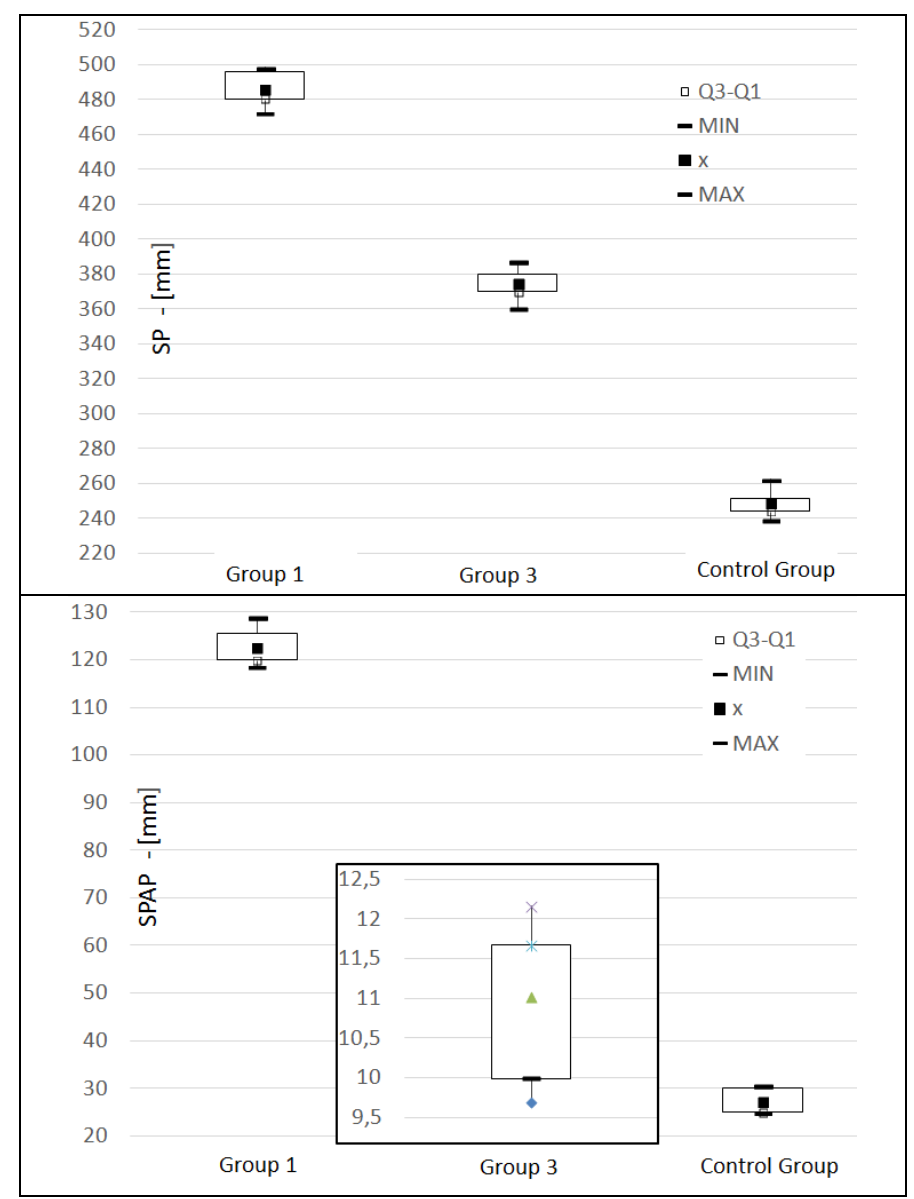




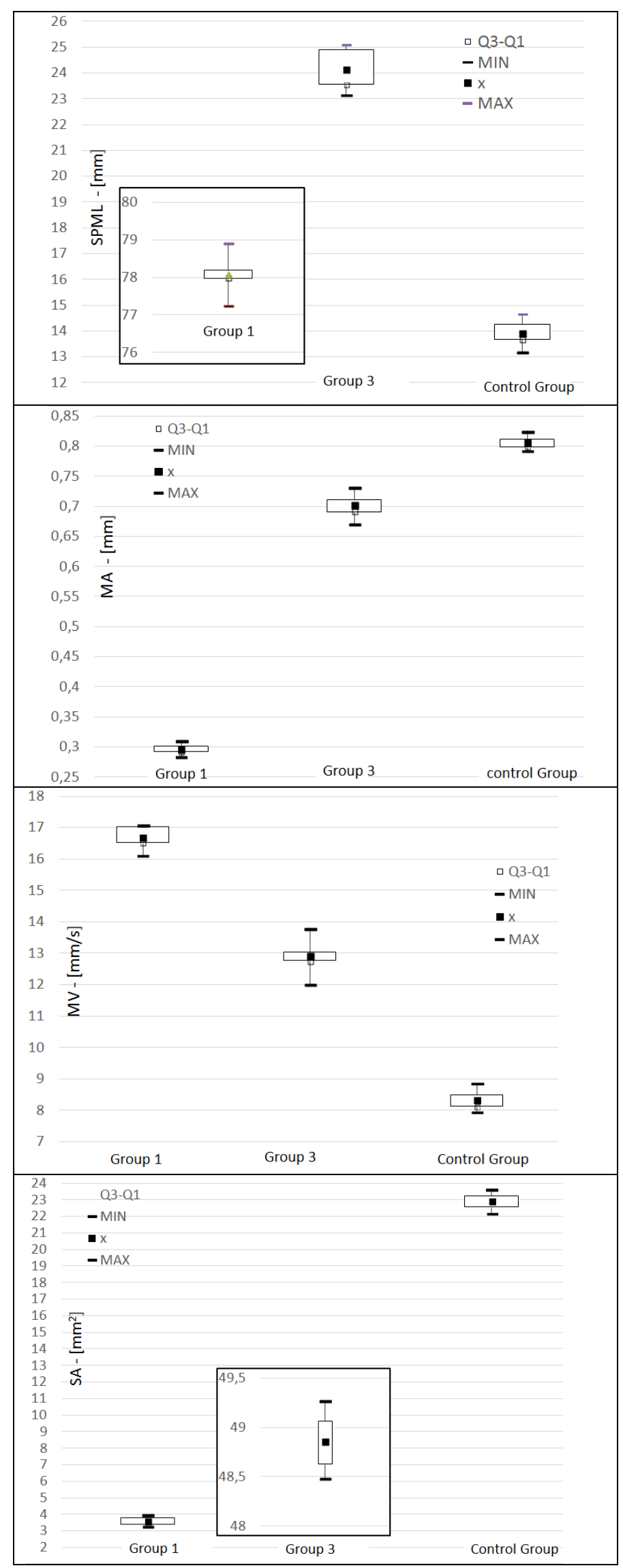


Table 11 Box plot of all motion parameters of the test $\mathrm{S}$ with opened eyes

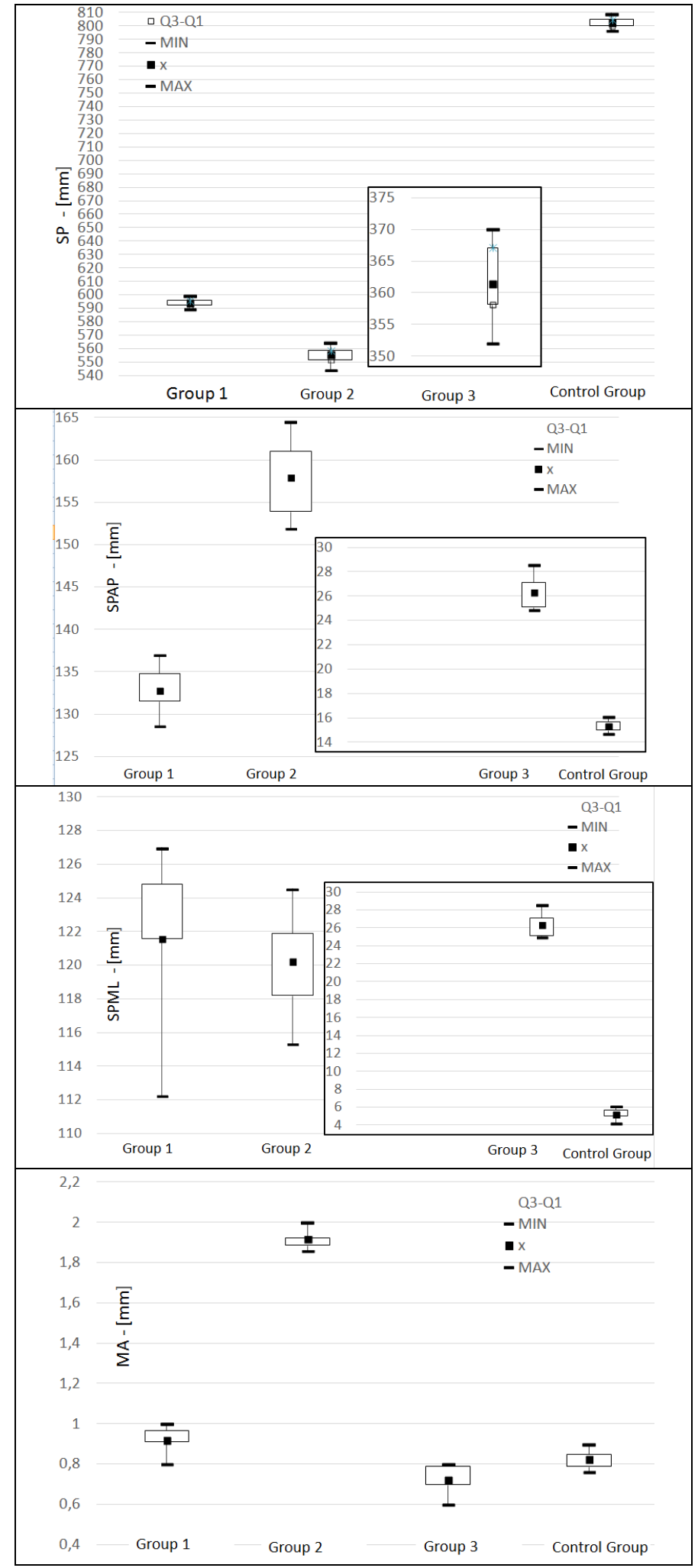




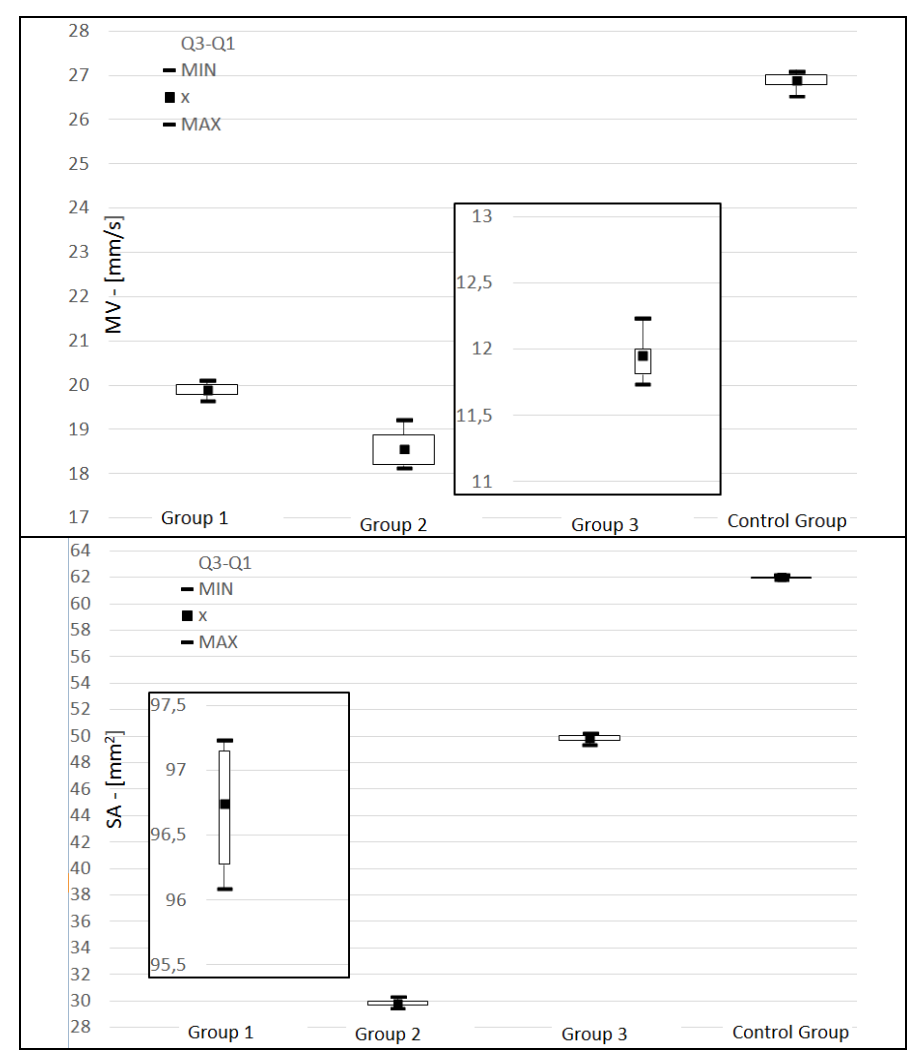

Table 12 Results of ANOVA and HSD tests of motion parameters of CoP for SCE

\begin{tabular}{|c|c|c|c|c|c|c|}
\hline & \multicolumn{2}{|c|}{ Anova } & Tukey's test & Group 1 and & Group 1 and & Group 3 and \\
\hline & F-test & $f_{a-1, v, \alpha}$ & HSD & group 3 & control group & control group \\
\hline$S P$ & 692,05 & 3,8853 & 16,979 & 111,366 & 236,818 & 125,452 \\
\hline SPAP & 1937,4 & 3,8853 & 5,1619 & 111,562 & 95,305 & 16,257 \\
\hline$S P M L$ & 12824,8 & 3,8853 & 1,1477 & 53,95 & 64,158 & 10,208 \\
\hline$M A$ & 1315,5 & 3,8853 & 0,0279 & 0,4052 & 0,5094 & 0,1042 \\
\hline$M V$ & 377,62 & 3,8853 & 0,8116 & 3,7522 & 8,352 & 4,599 \\
\hline$S A$ & 14698,8 & 3,8853 & 0,70605 & 45,2506 & 19,3194 & 25,9312 \\
\hline
\end{tabular}

Table 13 Results of ANOVA and HSD tests of motion parameters of CoP for SOE

\begin{tabular}{|l|c|c|c|c|c|c|c|c|c|}
\hline & \multicolumn{2}{|c|}{ Anova } & $\begin{array}{c}\text { Tukey's } \\
\text { test }\end{array}$ & $\begin{array}{c}\text { Group 1 and } \\
\text { group 2 }\end{array}$ & $\begin{array}{c}\text { Group 1 and } \\
\text { group 3 }\end{array}$ & $\begin{array}{c}\text { Group 1 and } \\
\text { control } \\
\text { group }\end{array}$ & $\begin{array}{c}\text { Group 2 and } \\
\text { group 3 }\end{array}$ & $\begin{array}{c}\text { Group 2 and } \\
\text { control } \\
\text { group }\end{array}$ & $\begin{array}{c}\text { Group 3 and } \\
\text { control } \\
\text { group }\end{array}$ \\
\hline & F-test & $f_{a-1, v, \alpha}$ & HSD & & & & & & \\
\hline$S P$ & 4194,3 & 3,239 & 11,2956 & $\mathbf{3 8 , 7 5 5}$ & $\mathbf{2 3 2 , 8 1}$ & $\mathbf{2 0 7 , 8 2}$ & $\mathbf{1 9 4 , 0 5 8}$ & $\mathbf{2 4 6 , 5 8}$ & $\mathbf{4 4 0 , 6 4}$ \\
\hline SPAP & 2689,86 & 3,239 & 5,684 & $\mathbf{2 5 , 1 0 8}$ & $\mathbf{1 0 6 , 5 2 6}$ & $\mathbf{1 1 7 , 5 0 2}$ & $\mathbf{1 3 1 , 6 3 4}$ & $\mathbf{1 4 2 , 6 1}$ & $\mathbf{1 0 , 9 6 7}$ \\
\hline SPML & 1591,73 & 3,239 & 6,222 & 1,344 & $\mathbf{9 5 , 2 2 8}$ & $\mathbf{1 1 6 , 3 2 8}$ & $\mathbf{9 3 , 8 8 4}$ & $\mathbf{1 1 4 , 9 8 4}$ & $\mathbf{2 1 , 1}$ \\
\hline$M A$ & 345,791 & 3,239 & 0,1204 & $\mathbf{0 , 9 9 5 7}$ & $\mathbf{0 , 1 9 8 9}$ & 0,0949 & $\mathbf{1 , 1 9 4 6 6}$ & $\mathbf{1 , 0 9 6 9}$ & 0,1039 \\
\hline$M V$ & 2133,09 & 3,239 & 0,5368 & $\mathbf{1 , 3 4 3 9}$ & $\mathbf{7 , 9 5 2 6}$ & $\mathbf{6 , 9 7 8 4}$ & $\mathbf{6 , 6 0 8 7}$ & $\mathbf{8 , 3 2 2 3}$ & $\mathbf{1 4 , 9 3 1}$ \\
\hline$S A$ & 29679,5 & 3,239 & 0,6602 & $\mathbf{6 6 , 9 0 7 7}$ & $\mathbf{4 6 , 8 8 1 7}$ & $\mathbf{3 4 , 7 2 7 8}$ & $\mathbf{2 0 , 0 2 5 9 8}$ & $\mathbf{3 2 , 1 7 9 0 4}$ & $\mathbf{1 2 , 5 3 0 6}$ \\
\hline
\end{tabular}

Tables 4, 5, 8, 9, 12, 13 contains results achieved with one-way ANOVA method. In all cases the $F$ results were greater than $f_{a-1, v, \alpha}$ which was calculated using equation (1). Therefore hypothesis about equality of mean values of motion parameters of CoP was 
rejected. It was found statistically significant influence of degree of visual impairment on stable position of patient.

Mentioned tables includes also results of Tukey-Kramer tests. Absolute values of difference of mean values between groups larger than calculated HSD value according to equation (2) are marked with boldface font in grey cells.

In case of LLCE variant, table 4, it was shown that degree of visual impairment significantly affect human stability. Only comparison of $1^{\text {st }}$ and $3^{\text {rd }}$ group for $M A$ parameter of the CoP and $1^{\text {st }}$ group with control group for SPML parameter of the CoP haven't revealed this dependence. Similar conclusions apply also to LLOE variant (table 5). Here there isn't statistical dependence between $1^{\text {st }}$ and control group in mean values of $M A, M V$ and $S A$ parameters of the CoP.

In case of RLCE variant, table 8, it was shown that degree of visual impairment significantly affect human stability. The observed difference between means of $1^{\text {st }}$ group and control group is not convincing enough to say that the moderate degrees of visually handicapped or partially blind differ significantly. It is known that path length $(S P)$ depends of time of recorded measurement and velocity. Therefore $S P, S A$, and $M V$ parameters are combined with each other. Then in case of RLOE variant, table 9, it was shown that degree of visual impairment significantly affects human stability.

In case of SCE variant and SOE, tables 12 and 13, it was shown that degree of visual impairment significantly affected human stability

\section{CONCLUSION}

The main goal of a pilot study and following statistical analysis was validation of the test procedure i.e. selection of patients for individual research group, applied measure instruments, body positions during tests. Results from statistical analysis obtained from pilot studies are only demonstrative.

Independent variable divided test to 3 (variant with open eyes 4) categories, there were no possibility to apply $t$ test. Therefore data were checked to met the assumptions of one-way ANOVA test. Kolmogorov-Smirnov and Levene's tests confirmed that this method can be used. In each case obtained $p$ - value was less than established level of significance $\alpha=0.05$, therefore method from chapter 3 was used.

Although this was a pilot study, the its results given interesting, but not fully clear results, showing that there is the relationship between the visual impairment of patient and his postural stability. Studies proved that degree of visual impairment affected patients balance control. Research noticed, what is described on box plots, that body's larger imbalance differences are in case when eyes are closed than open.

Basing on values from stabilogram, which describes displacement value of the CoP, six different motion parameters of the CoP were compared, for each variants - with closed and open eyes. Observations says that the length of the path $S P$ in almost every variant, excluding $S$ variant, increased significantly in tests with closed eyes (tables 2, 3, 6, 7, 10, 11). Excluding visual control was important in this case for all groups.

It was also observed that there are differences in SPAP parameter value between tests with open and closed eyes. In LL variant closed eyes for all patients caused its increase causing instead decrease value of $S P M L$ parameter. The same situation refers the increase of the $S A$ parameter. In case of $\mathbf{R L}$ variant parameter disabling visual control doesn't affected significantly on SPAP parameter, only value $S P M L$ for $1^{\text {st }}$ and control group increased a lot. 
For $3^{\text {rd }}$ group these values doesn't changed or changed a little. In case of $\mathbf{S}$ variant value of $S P A P, S P M L$ and $M A$ parameters decreased or was changing a little with disabled visual control for $1^{\text {st }}$ and $3^{\text {rd }}$ group but increased for control group. Reverse changes were for $S A$ parameter.

Summarizing, this a pilot study demonstrated that developed research procedure which investigates influence of eye dysfunction on postural stability is reliable.

\section{REFERENCES}

[1] Błaszczyk J. W.: Biomechanika kliniczna, Wydawnictwo Lekarskie PZWL, Warszawa 2004

[2] Dz. U. Nr 139, poz. 1328. 32 ust. 1 pkt 4 rozporządzenia Ministra Gospodarki, Pracy i Polityki Społecznej z dnia 15 lipca 2003 r. w sprawie orzekania o niepełnosprawności i stopniu niepełnosprawności

[3] Goebel J. A. (Editor): Practical Management of the Dizzy Patient. Lippincott Williams \& Wilkins Publ. 2000.

[4] Guskiewicz K. M., Ross S. E., Marshall S. W.: Postural Stability and Neuropsychological Deficits after Concussion in Collegiate Athletes. J Athl Train. 2001 Jul-Sep; 36(3), 263 273.

[5] Jernigan K.: The Nature of Independence, An Address at the Convention of the National Federation of the Blind. Dallas, 1993

[6] Rama Kotaiah K., Srinivas J., Babu K. J., Rama Prasad A. V. S.: Stability analysis of turning the continuous workpiece model. Journal of Mechanical Engineering - Strojnicky časopis, Vol. 61, No. 2, 2010, pp. $89-104$

[7] Xu-ing J.: Optimum synthesis method of mechanical press driven by non-circular gears. Journal of Mechanical Engineering - Strojnicky časopis, Vol. 63, No. 3, 2012, pp. 155 168

[8] Kapteyn T. S., Bles W., Njiokiktjien C. J., Kodde L., Massen C. H., Mol J. M.: Standardization in Platform Stabilometry being a Part of Posturography. Agressologie: Revue Internationale de Physio-biologie et de Pharmacologie Appliquees aux Effets de L'agression 1983 Jun; 24(7), 321-326.

[9] Nashner L. M. et al.: Adaptation to altered support and visual conditions during stance: patients with vestibular deficits. J Neurosci. 1982 May; 2(5), 536-44.

[10] Ahrens H., Läuter J.: Wielowymiarowa analiza wariancji, PWN, Warszawa 1979.

[11] Bartolucci A. A., Singh K. P., Bae S.: Introduction to statistical analysis of laboratory data. John Wiley \&Sons, 2016.

[12] Boddy R., Smith G.: Statistical Methods in Practice. John Wiley \&Sons, 2009.

[13] Starzyńska W., Statystyka praktyczna, PWN, Warszawa 2009.

[14] Tamhane A. C.: Statistical Analysis of Designed Experiments: Theory and Applications. John Wiley \&Sons, 2009. 